\title{
Project Studies as A Transborder Didactic Tool in Higher Education (The Case of The German- Russian Study Project)
}

\author{
Bernd-Joachim Ertelt ${ }^{1 *}$, Roman Kondurov ${ }^{1}$, Michael Scharpf ${ }^{1}$, Sergey A. Barkov ${ }^{2}$, Inna V. \\ Kolodeznikova ${ }^{2}$ \\ ${ }^{1}$ University of Applied Labour Studies, Mannheim, Germany \\ ${ }^{2}$ Lomonosov Moscow State University, Economic Sociology and Management Subdepartment, \\ Department of Sociology, Moscow, Russia
}

\begin{abstract}
Project studies can become the most important innovative component of education programs in modern society. They allow one to not only improve the professional skills of students, but also develop competencies in the fields of project management and team building. The greatest didactic value is possessed by interdisciplinary and international projects. In the framework of their implementation, a synergistic effect occurs from a combination of methods of different sciences, as well as communications between representatives of different national scientific and educational schools. The success of a project study depends on student motivation. Their participation in setting common goals and developing methods for their achievement is the basis of high motivation. Along with this, the work of teacher-curators, oriented to help in solving emerging problems of a substantial and methodological order, acquires a fundamental role. The lack of project studies is largely due to the high requirements for the teachers involved in it. The tasks of teachers during project training are fundamentally different from those that they perform using other educational methods. This is one of the most temporarily costly and time-consuming forms of training. The study deals with the structural, managerial and didactic features of project study in higher education using as an example scientific and educational projects on labour market studies, which, since 2017, have been jointly carried out by the Moscow State University (MSU) and the University of Applied Labour Studies (UALS), Mannheim.
\end{abstract}

\section{Introduction}

For many years, project management has been "the main strategy or the core of the further development of organizations" [1]. Project activity was of great importance for universities, both in didactics and in scientific cooperation between universities [2]. As part of the implementation of university projects, a positive effect can be achieved for all the above areas of life: business, education and science. Applications can reinforce each other. If in the process of training students acquire the skills of effective teamwork within the framework of

\footnotetext{
* Corresponding author: Bernd-Joachim.Ertelt@ arbeitsagentur.de
} 
the project, this will positively affect their subsequent professional activities in enterprises, firms, etc., both in research and teaching. At the same time, project work contributes to the development of a sense of time, self-management skills, as well as the ability to reflect and present results [3].

\section{Structural and didactic aspects of project study in education}

Project study is fundamentally different from other types of educational work because in terms of the structure of the task they represent the so-called "open learning situation", which, as a rule, does not imply the presence of clear or predetermined solutions. Since in this case the volume and structure of the task ("subject structure") is difficult to assess, the necessary requirements for training and the course of mental actions ("learning structure") can be more accurately determined only in the course of the project work itself.

Systematic planning and implementation of project work require a clear definition of goals, specification of tasks, as well as preparation of a work plan with time steps and allocation of responsibilities to specific performers. Of particular importance for successful work on a project is a motivating identification of goals, directly related to a realistic assessment of the attainability of the results [4]. As part of this stage, to optimize the work, one can use the SMART model, according to which the target indicators of the results should be specific, measurable, acceptable, realistic and planned [1]. The participation of students in the development of the plan is fundamentally significant in terms of their training in managerial skills. They must correlate the logic and chronology of the study process, highlighting the relationship of its individual stages and directions [5].

Among modern education programs, interdisciplinary projects [6], public administration projects [7] and career guidance [8] are especially attractive. In the framework of interdisciplinary projects, students are given the opportunity to study individual socially, politically and economically significant problems using a specific set of methods that are usual for different sciences. The central issue, in this case, is the combination of these scientific methods with the possibility of applying study results in practice. This combination serves as the basis for the high motivation of students to implement the project.

There are other motivational imperatives for project development. Educational projects should contain important and relevant topics, touch on the fundamental matters of the subject, show the connection of training with subsequent professional practice, and also take into account the interests and abilities of students $[9,10,11,12,13]$. Overfatigue, as well as an easy task, during the implementation of the project reduces motivation. Motivation may decline not only due to errors in setting goals, but due to poor selection of funds. Means must be consistent with the goal and facilitate the path to achieving it. To avoid negative motivation for learning, teachers responsible for a project should offer students processoriented knowledge (for example, tips on analyzing the problem, creating and testing hypotheses), give an idea of already existing knowledge about a subject, and disclose sources of information so that students can collect and analyze them $[14,15]$.

The main goal of a project is to give students an opportunity to directly participate in the study process and gain relevant knowledge $[16,17]$. In the process of project implementation, a steady relationship is established between study, teaching and learning. Such a combination requires skills from both students and teachers [18]. Ideally, students acquire the ability to develop solutions to specific complex problems in a study and reflective manner [12]. The tasks of teachers during project training are fundamentally different from those that they perform using other educational methods. This is one of the most temporarily costly and time-consuming forms of training. The complexity of a teacher's work on the project is the reason why project study has so far been rarely offered as compulsory courses in universities or almost never been included in the curriculum of education programs [19]. 
Project study requires teachers to synthesize professional knowledge, teaching methods and didactic skills. "In an active, student-oriented, as well as competence-oriented didactic environment, students, together with teachers, experience the cognitive, emotional and social aspects of the entire study process, which begins with curiosity and the initial questions, goes through its various stages and ends with finding a solution to the problem and its presentation" [20]. If we detail the work of a teacher during the implementation of a project, we can conclude that they should be competent in the following areas of activity:

- a guiding effect in setting goals and drawing up a project plan;

- individual professional and methodological consultations during and between the phases of a project;

- assessment and analysis of the results of meetings during a project;

- support for joint activities of student working groups, for example, during interviews, opinion polls, and discussions with interested parties;

- coordination of work between various project teams;

- final assessment of project work;

- organization of the presentation of results by project teams and, if possible, preparation of results for publication.

\section{German-Russian university labour market study project}

All the methodological features of the design studies presented above have proved themselves in the course of the implementation of scientific and educational projects, which since 2017 have been jointly carried out by the Moscow State University (MSU) and the University of Applied Labour Studies (UALS), Mannheim. In the implementation of the project since the beginning, the parties set themselves the following goals:

- implementation of scientific student exchange;

- formation of teamwork skills among students (including work experience in an international team);

- development of intercultural interaction experience;

- conducting comparative studies to identify country specifics in the labour markets of Russia and Germany in the studied areas and identify best practices for the possible subsequent implementation of the employment services of Russia and Germany in practice;

- acquisition of knowledge about the state and prospects of the Russian and German labour markets, as well as German and Russian labour administration.

At the end of each session of the project, the parties also planned a broad exchange of study results, including the holding of scientific conferences, the production and demonstration of posters and the publication of results in European and Russian journals. The plan also included the expansion of cooperation between the two universities: the implementation of new study projects and attracting new partners to cooperation.

To date, three sessions of the project have already taken place. Each session begins with intensive preparation: project managers and curators meet to discuss future topics. Then students are selected, and 16 students from Mannheim and Moscow each year become participants in the project. Each project cycle includes topics from various subject areas sociology, management consulting and public administration. Since 2018, project work stuck with one topic. Each subgroup of students, including two Russian and German participants, is working on a separate aspect of the general theme of the project. The study takes place throughout the school year - from October to May. During this time, visits to both universities are provided. In the interim period, project participants maintain constant communication with each other using modern means of communication. At the end of the empirical studies, students compare their results in two countries and form the final joint 
presentation. At the end of the project, a joint presentation and discussion of the results of the study are carried out.

At the University of Applied Labour Studies, this project study is included in the curriculum of the bachelor's degree programs "Labour Market Management" and "Guidance for Education, Career and Employment" as a compulsory subject [8]. Moscow State University currently offers students an optional form of participation in the project.

From the first session of the project, project managers from both universities attach great importance to the choice of project topics. Priority is given to practical, interdisciplinary topics that are especially relevant for enterprises, employment services, as well as for the development of labour markets and vocational training in Germany and Russia. During the work, several blocks of topics were investigated. In 2017/2018, the study was commissioned by the Ministry of Labour and Social Protection of the Russian Federation (Rostrud). This determined the following study topics for project participants:

- transformation of company management and labour mobility of the workforce;

- postindustrial employment trends and long-term unemployment;

- features of the functioning of social insurance systems in Russia and Germany;

- education programs of employment services and companies;

- for job seekers.

The study results were presented in April 2018 in Rostrud at a conference call with representatives of the regions. The results were published four joint articles in the journal "Vestnik Moskovskogo universiteta. Seriya 18. Sotsiologiya i politologiya" ("Moscow State University Bulletin. Series 18. Sociology and Political Science") prepared by the Russian and German curators of the project in collabouration with the Russian students who participated in the project.

In 2018/2019, the general theme "Family and Career" was chosen for the study. Within its framework, the following aspects were investigated:

- the influence of the family on the choice of profession (attitude to working dynasties);

- finding a balance between work and personal life;

- downshifting as a strategy of work and life;

- the role and tasks of the employment service in assisting women in returning to work after the family phase.

In 2019/20, the study was carried out under the general theme "The Future of Labour". Students of the Faculty of Sociology explored the following topics:

- labour degradation (dequalification) of workers in the era of automation and computerization;

- involvement of older people in active labour, new opportunities in the digital age;

- the impact of social networks on employment;

- outsourcing as a factor determining employment and career in a postindustrial society.

Students of the School of Public Administration investigated the following topics:

- cooperation (opportunities and limitations) of public and private employment services in the conditions of 4.0 ;

- problems and trends of public employment services in the digital age;

- knowledge management as a tool to preserve the experience of older workers in the context of digitalization;

- career management and employment in the world 4.0: challenges for public employment services.

Both sides of the project greatly appreciate teamwork. The main factors affecting the success of past and future projects, the parties consider:

- relevant selection of topics and thorough preparation of the project;

- involvement and enthusiasm of teacher-curators of the project;

- a responsible approach to the selection of students to participate in the project; 
- integration of design studies into the educational process;

- cooperation with companies and employment services during the project;

- conducting team building activities for students;

- comparison of results and exchange of results at the end of areas project;

- an exchange of views between students and teachers after each round of the project.

The three years of experience working together to date, allows us to identify not only constructive professional cooperation, but also a friendly atmosphere, which invariably develops from year to year as among the students. between teachers and curators participating in the project from the Russian and German sides as factors that largely determine the success of the project.

\section{Conclusion}

The results of work in the project for students go far beyond mere acquaintance with study methods. Under the guidance of teachers, students also learn group work skills and gain valuable experience working in an international team. Participation in such projects also encourages students to continue their scientific activities: preparing articles on the results of studies for publication in scientific journals and participating in other European projects.

\section{References}

1. C. Schiersmann, H.-U. Thiel. Organisationsentwicklung (Springer VS., 2018)

2. C.L. Chiang, H. Lee, International Journal of Information and Education Technology 6(9), (2016)

3. M. MacLeod, J.T. Van der Veen, European Journal of Engineering Education 45(3), 363-377 (2019)

4. K.M.Y. Law, S. Geng, T. Li, Computers \& Education 136, 1-12 (2019)

5. D. Beard, D. Schweiger, K. Surendran, Journal of Information Systems Education 19(2), 229-240 (2018)

6. S.E. Kruck, F.P. Teer, Journal of Information Systems Education 20(3), 325-330 (2019)

7. R. Dincher, M. Scharpf, Management in der öffentlichen Verwaltung: Führung, Steuerung, Controlling (Forschungsstelle für Betriebsführung und Personalmanagement, Neuhofen, 2018).

8. B.-J. Ertelt, A. Frey, M. Scharpf, Berufsberatung als Wissenschaft.Vier Jahrzehnte akademische Ausbildung für Berufsberater in Mannheim (Hamburg, 2015).

9. D. Ley, Emerging technologies for learning, Web 2.0 and Libraries (2010)

10. Center for Teaching \& Learning, Projects-Based Learning: teaching guise (Boston, 2020) Available at: www.bu.edu/ctl/guides/project-basedlearning

11. J. Schulte, K. Linke, B. Bachmann, Journal "die hochschullehre" 4, 583-604 (2018)

12. J. Rein, Hochschuldidaktik und wissenschaftsbezogene Reflexion. In: Spieker-mann, Lehrforschung wird Praxis (Bielefeld, 2013).

13. K. Reich, Projektarbeit (2020) Available at: www.methodenpool.uni-koeln.de

14. K. Suchotzki, M. Gamer, Psychophysiology 56(1), (2019)

15. P.A. Jennings, J.L. Brown, J.L. Frank, S. Doyle, Y.Oh, R. Davis, D. Rasheed, A. De Weese, A.A. De Mauro, H. Cham, M.T. Greenberg, Journal of Educational Psychology 109(7), 1010-1028 (2017)

16. N. Plotnikova, E.N. Strukov, Cypriot Journal of Educational Sciences 14(1), 1-10 (2019) 
17. E. Jung, Projektunterricht - Projektstudium - Projektmanagement (2016) Available at: Retrieved from: www.sowi-online.de

18. E. Munthe, Teaching and Teaching Education 67, 37-45 (2017)

19. P. Shekhar, M. Prince, C. Finelli, M. Demonbrun, C. Waters, European Journal of Engineering Education 44, 6-18 (2019)

20. T. Jungmann, Forschendes Lernen im Ingenieurstudium: research-based Learning. In: Janke, I; Wildt, J. (Hrsg.): Fachbezogene und fachübergreifende Hochschuldi-daktik (Bielefeld, 2011). 